' Fomon, S J, et al, Acta Paediatrica Scandinavica, 1971, suppl No 223, p 1.

${ }^{8}$ Fomon, S J, Owen, G M, and Thomas, L N, American fournal of Diseases of Children, 1964, 108, 601 .

${ }^{9}$ Salariya, E M, Easton, P M, and Cater, J I, Lancet, 1978, 2, 1141.

${ }^{10}$ Dahms, B B, et al, fournal of Pediatrics, 1973, 83, 1049.

11 Campbell, N, Harvey, D, and Norman, A P, British Medical fournal, 1975, 2, 548.

12 Eastham, E, et al, British Medical fournal, 1976, 1, 305.
${ }^{13}$ Fomon, S J, et al, Acta Paediatrica Scandinavica, 1970, suppl No 202, $\mathrm{p} 1$.

14 Bullen, C L, and Willis, A T, British Medical fournal, 1971, 3, 338

${ }_{15}$ Gunther, M, et al, International Archives of Allergy, 1962, 21, 257.

${ }_{16}$ Whorwell, P J, et al, British Medical fournal, 1979, 1, 382.

17 Cruse, P, Yudkin, P, and Baum, J D, Archives of Disease in Childhood, 1978, 53, 76.

(Accepted 3 August 1979)

\title{
De novo acute infection and reactivation of hepatitis $B$ virus in established cirrhosis
}

\author{
A THEODOSSI, S P W WILKINSON, B PORTMANN, Y WHITE, A L W F EDDLESTON, \\ ROGER WILLIAMS, A J ZUCKERMAN
}

British Medical fournal, 1979, 2, 893-895

\section{Summary and conclusions}

Five patients with cirrhosis proved by biopsy had clinical, biochemical, and serological evidence of an acute hepatitis $B$ infection. In two the illness was fulminant and led to death. Only one patient completely recovered. Serological markers for the hepatitis $B$ virus were absent before the onset of the acute illness in four patients, which suggested that a de novo infection had been acquired as a result of recent transfusions of blood or blood products. The fifth patient, who had Goodpasture's syndrome, had antibody to the core of hepatitis $B$ virus, indicating previous exposure to the virus; his acute hepatitis may have been related to immunosuppressive drug treatment, which may have reactivated a dormant virus infection.

Thus an acute type $B$ viral hepatitis due to either a de novo or a reactivated infection may be superimposed on cirrhosis.

\section{Introduction}

Jaundice with biochemical characteristics of hepatocellular injury with established cirrhosis may have several causes. In the alcoholic it is often a manifestation of acute alcoholic hepatitis, and in this and other aetiological groups may indicate decompensation precipitated by sepsis, gastrointestinal haemorrhage, or hepatocellular carcinoma. Patients with cirrhosis may also be at special risk of contracting acute hepatitis, since their management often entails admission to hospital and giving blood transfusions and other parenteral preparations. "Non-A,

Liver Unit, King's College Hospital and Medical School, London SE5 8RX

A THEODOSSI, $M B, M R C P$, clinical research fellow

S P W WILKINSON, MD, MRCP, senior medical registrar

B PORTMANN, MRCPATH, honorary consultant histopathologist

Y WHITE, DIPMLT(SA), senior technician

A L W F EDDLESTON, DM, FRCP, senior lecturer and honorary consultant physician

ROGER WILLIAMS, MD, FRCP, consultant physician and director of unit

London School of Hygiene and Tropical Medicine, London

A J ZUCKERMAN, MD, FRCPATH, professor of microbiology
non-B" hepatitis acquired by administration of clotting-factor concentrates in patients with cirrhosis has been described, ${ }^{1}$ but we are unaware of reports of parenterally acquired acute hepatitis type $B$ infection.

In this report we describe five patients with presumed alcoholic cirrhosis in whom jaundice was related to an acute-type hepatitis B. Four patients had de novo infections, possibly acquired from blood or blood products, while serological findings in the other indicated reactivation of.a latent infection.

\section{Clinical findings}

In each case the liver disease had been fully assessed in this unit before the acute hepatitis developed.

\section{CASES $1-4$}

Cirrhosis was present in each case and was attributable to heavy alcohol consumption for many years. None of the patients had had encephalopathy or gastrointestinal haemorrhage, but two (cases 1 and 3) had had ascites, which responded to diuretics; one (case 3 ), because of appreciable piecemeal necrosis on liver biopsy, was receiving prednisone $(20 \mathrm{mg}$ /day). Representative liver function tests before the acute hepatitis indicated moderately well-compensated cirrhosis (table). All patients were negative for the following markers of hepatitis $B$ infection as measured by radioimmunoassay: surface antigen ( $\mathrm{HBsAg}$ ); antibody to surface antigen (anti-HBs); and antibody to core antigen (anti-HBc).

Each patient was subsequently admitted with an acute illness characterised by a prodrome of anorexia and malaise followed by deepening jaundice (maximum bilirubin concentration ranging from 147 to $459 u \mathrm{~mol} / 1(8 \cdot 6-26.8 \mathrm{mg} / 100 \mathrm{ml})$ (table). Aspartate aminotransferase concentration and prothrombin time also increased (237 to $2050 \mathrm{IU} / 1$ and 12 to 26 seconds respectively). On admission the serum was positive for $\mathrm{HBsAg}$. During the preceding two, three, four, and eight months each of the four patients had received blood or blood products-namely, fresh frozen plasma as "cover" for a liver biopsy in cases 1, 2, and 3, and blood transfusions for epistaxis in case 4.

Two patients (cases 1 and 2) rapidly lapsed into hepatic coma and died 12 and two days respectively after admission. The remaining two patients showed less severe signs of encephalopathy (confusion and disorientation) and subsequently improved; in each case the serum became $\mathrm{HBsAg}$-negative. One patient (case 3) was discharged from hospital and found to be positive for anti-HBs five months later. The other patient (case 4), although apparently recovering from the acute hepatitis, later developed other complications including a spontaneous bacterial peritonitis and died four months after admission. 
Laboratory data before, during, and after acute hepatitis

\begin{tabular}{|c|c|c|c|c|c|c|c|c|c|c|c|}
\hline \multirow{2}{*}{$\begin{array}{l}\text { Case } \\
\text { No }\end{array}$} & \multirow{2}{*}{ Sex } & \multirow{2}{*}{$\begin{array}{c}\text { Age } \\
\text { (years) }\end{array}$} & \multicolumn{3}{|c|}{ Serum bilirubin $(\mu \mathrm{mol} / \mathrm{l})$} & \multicolumn{3}{|c|}{ Aspartate aminotransferase (IU/1) } & \multicolumn{3}{|c|}{ Prothrombin time (s prolonged) } \\
\hline & & & Before & During & After & Before & During & After & Before & During & After \\
\hline $\begin{array}{l}1 \\
2 \\
3 \\
4 \\
5\end{array}$ & $\begin{array}{l}\mathbf{M} \\
\mathbf{M} \\
\mathbf{F} \\
\mathbf{F} \\
\mathbf{M}\end{array}$ & $\begin{array}{l}37 \\
55 \\
40 \\
54 \\
52\end{array}$ & $\begin{array}{l}36 \\
40 \\
74 \\
56 \\
11\end{array}$ & $\begin{array}{r}459 \\
.149 \\
196 \\
147 \\
121\end{array}$ & $\begin{array}{r}306 \\
220 \\
26\end{array}$ & $\begin{array}{l}75 \\
44 \\
78 \\
82 \\
31\end{array}$ & $\begin{array}{r}250 \\
237 \\
2050 \\
1050 \\
700\end{array}$ & $\begin{array}{l}118 \\
114 \\
179\end{array}$ & $\begin{array}{l}5 \\
8 \\
5 \\
5 \\
2\end{array}$ & $\begin{array}{r}26 \\
16 \\
18 \\
12 \\
2\end{array}$ & $\begin{array}{l}6 \\
8 \\
2\end{array}$ \\
\hline
\end{tabular}

Conversion: SI to traditional units-Serum bilirubin: $1 \mu \mathrm{mol} / 1 \approx 0.06 \mathrm{mg} / 100 \mathrm{ml}$.

CASE 5

This 51-year-old man had been treated since 1973 for Goodpasture's syndrome with predisone, $80 \mathrm{mg}$ daily, and cyclophosphamide, $200 \mathrm{mg}$ daily (fig 1). He had a history of heavy alcohol con-

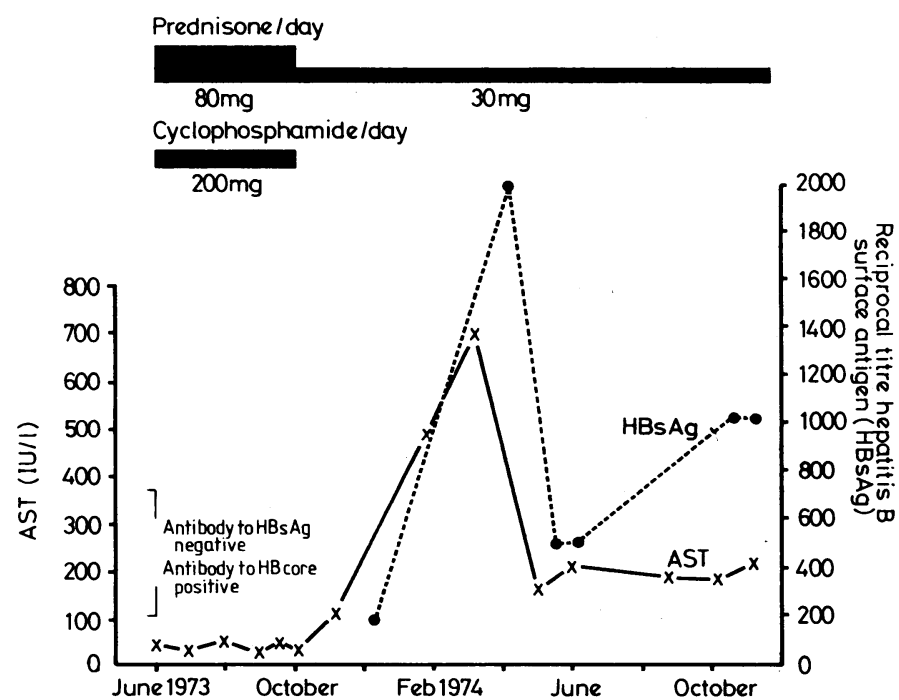

FIG 1-Serial data relating to biochemical and serological events in case 5 . AST $=$ Aspartate aminotransferase.

sumption for many years, and although liver function tests had never shown any abnormality (table), liver tissue obtained during attempted renal biopsy showed features of cirrhosis. At presentation the serum was negative for both $\mathrm{HBsAg}$ and anti-HBs but, in contrast to cases 1-4, was positive for anti-HBc. Five months later, after a haemorrhage from a duodenal ulcer (not requiring blood transfusion), the dose of prednisone was reduced to $30 \mathrm{mg}$ daily and the cyclophosphamide discontinued because of leucopenia. Two months later a routine blood sample was positive for $\mathrm{HBsAg}$, and after a further two months he developed an acute illness with anorexia, malaise, arthralgia, and jaundice. Serum bilirubin concentrations rose to $121 \mu \mathrm{mol} / 1(7 \cdot 1$ $\mathrm{mg} / 100 \mathrm{ml}$ ) and aspartate aminotransferase to $700 \mathrm{IU} / \mathrm{l}$. With this illness the HBsAg titre increased eightfold. During the next six weeks the symptoms of his acute hepatitis and the results of liver function tests improved, but the serum remained positive for $\mathrm{HBs} \mathrm{Ag}$. He died six months later from a massive pulmonary embolus.

\section{HISTOLOGICAL FINDINGS}

Needle biopsy specimens taken before the acute hepatitis in cases $1,2,3$, and 4 showed a micronodular cirrhosis of an alcoholic type with Mallory's hyaline and polymorphonuclear infiltrate and, in case 3, collections of mononuclear cells within the fibrous septa and portal tracts with infiltration into the lobules (piecemeal necrosis). The initial biopsy in case 5 showed a macronodular cirrhosis with no specific aetiological features. Further biopsy specimens taken to investigate the acute hepatitis (in cases 1 and 2 immediately after death and in cases 4 and 5 two and five weeks respectively after presentation) showed changes characteristic of acute hepatitis superimposed on the chronic liver disease with liver-cell loss, residual eosinophilic necrosis, and a mixed cellular infiltrate including pigment-laden macrophages and plasma cells (fig 2). Surviving liver cells were hyperplastic with frequent rosette arrangements and were pale-staining. Bile-duct structures proliferated.

In cases 4 and 5 final biopsies four and nine months later showed that the changes in case 4 had disappeared, although they persisted to a. lesser degree in case 5 . Orcein staining for $\mathrm{HBsAg}$ in hepatic cells from cases 1-4 was negative. In case 5 the initial specimen was also negative, but specimens taken during the acute hepatitis and at necropsy were positive.

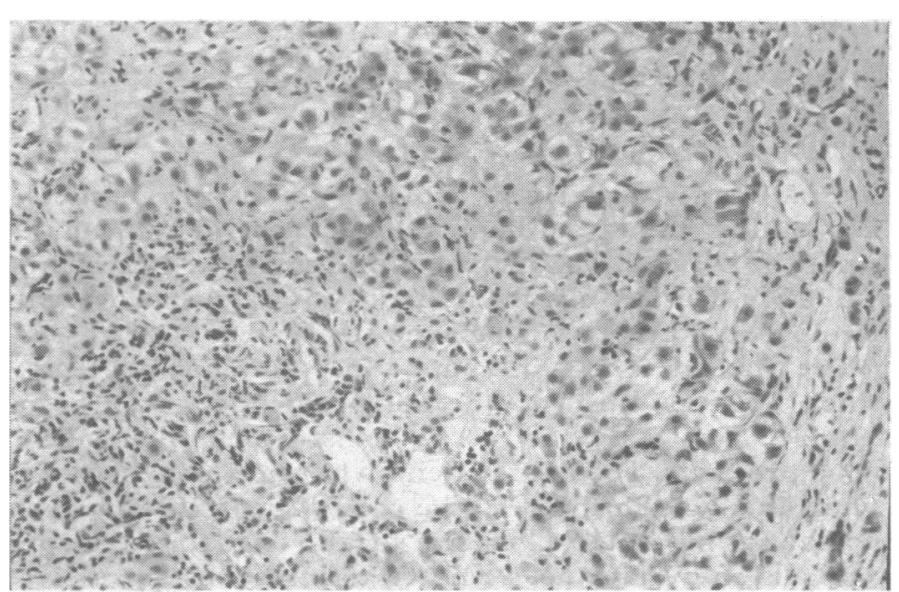

FIG 2-Liver biopsy specimen from case 4 showing severe inflammatory infiltrate with areas of confluent necrosis in the regenerating nodule. Haematoxylin and eosin $\times 50$ (original magnification).

\section{Discussion}

The characteristics of the acute illness in each of these cases, with an appreciable rise in serum aminotransferase concentration

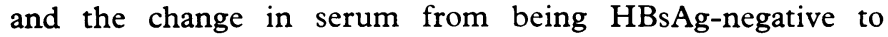
HBsAg-positive, point to an acute type B viral hepatitis. Although acute changes such as spotty necrosis, lobular, portal, and septal infiltrates with neutrophils, and Kupffer-cell hyperplasia may all occur as part of the histological manifestation of cirrhosis, ${ }^{2}$ the intensity and widespread distribution of these changes suggest a superimposed and new acute hepatitis. Failure to detect anti-HBs or anti-HBc antibodies in the serum as well as the absence of $\mathrm{HBsAg}$ before the acute episode suggest a de novo infection, possibly from the fresh frozen plasma and blood transfusion.

One patient (case 5) had anti-HBc antibody in serum nine months before the acute hepatitis, which indicated previous exposure to the hepatitis $B$ virus. ${ }^{3}$ Thus the acute hepatitis could have been caused by a reactivation of a dormant hepatitis $B$ virus infection, as has been observed in patients undergoing renal transplantation. ${ }^{+}$Immunosuppression may, by diminishing immune response to the virus, permit an increase in viral replication sufficient for expression of $\mathrm{HBsAg}$ in the serum. Wands et al found that the anti-HBs titre fell after cytotoxic drug treatment had been started in 17 patients with lymphoproliferative disorders who were initially positive for anti-HBs; 
five became $\mathrm{HBsAg}$-positive coincident with the fall in antiHBs titres. We have seen another patient with underlying cirrhosis due to chronic active hepatitis in whom a dormant hepatitis $B$ virus infection may also have been reactivated after immunosuppressive treatment. ${ }^{6}$ The acute attack of hepatitis in case 5 may have been due instead, however, to a new infection with a different subtype of hepatitis B virus. Reports of the coexistence of antigen and antibody of different subtypes in the same serum suggest that a second infection can occur in previously exposed individuals. ${ }^{i} 8$

Another difference between cases 1-4 and case 5 lies in the histological findings. Only the patient in case 5 , who remained $\mathrm{HBsAg}$-positive, had orcein-positive hepatocytes, indicating the presence of HBsAg. This supports other observations that positive orcein staining is more typical of those patients who progress to chronic hepatitis B infection. ${ }^{9}$

Patients receiving frequent transfusions for recurrent variceal haemorrhage or given fresh frozen plasma as a cover for liver biopsy are likely to be at greatest risk. Hoofnagle et al ${ }^{10}$ showed that donor blood negative for both $\mathrm{HBs} A g$ and anti-HBs can still be infectious if positive for anti- $\mathrm{HBc}$, and the latter marker may be valuable when the $\operatorname{IgM}$ component is raised. Non-A, non-B hepatitis is also transmitted by transfusion, and we have seen several cases of acute hepatitis due to this infection in patients with chronic liver disease. ${ }^{1}$

We are grateful to the department of chemical pathology and Mrs Hazel Smith for valuable help, and to the Wellcome Trust and the Department of Health and Social Security for generous support.

\section{References}

1 Wyke, R J, et al, Lancet, 1979, 1, 520

2 Anthony, P P, et al, fournal of Clinical Pathology, 1978, 31, 395.

3 Hoofnagle, J H, Gerety, R J, and Barker, L F, Lancet, 1973, 2, 869

${ }^{4}$ Nagington, B, Cossart, Y E, and Cohen, B J, Lancet, 1977, 1, 558.

5 Wands, J R, et al, Gastroenterology, 1975, 68, 105.

6 Villa, E, et al, submitted for publication.

7 Suzaki, T, et al, Immunology, 1976, 117, 2258.

${ }^{8}$ Koziol, D E, et al, Immunology, 1976, 117, 2260.

9 Portmann, B, et al, Gut, 1976, 17, 1.

${ }^{10}$ Hoofnagle, J H, et al, New England fournal of Medicine, 1978, 298, 1379.

(Accepted 31 fuly 1979)

\title{
Comparison of buprenorphine and pethidine given intravenously on demand to relieve postoperative pain
}

\author{
K CHAKRAVARTY, W. TUCKER, M ROSEN, M D VICKERS
}

British Medical fournal, 1979, 2, 895-897

\section{Summary and conclusions}

In a double-blind study of on-demand intravenous analgesia buprenorphine was found to be about 600 times as potent as pethidine. The incidence of side effects was similar with both drugs. The quality of analgesia, subjectively assessed, was good with both drugs using this method of administration.

Provided that its low potential for abuse is substantiated, buprenorphine appears to be a powerful analgesic that may successfully be given intravenously on demand.

\section{Introduction}

Using patient-controlled devices to administer intravenous narcotic analgesics has been described. ${ }^{1-3} \mathrm{~A}$ motorised syringe with a demand hand grip, and containing several important safety features, has been used for pain relief in obstetrics for several years in this hospital. ${ }^{4}$ We report a trial comparing buprenorphine and pethidine in relieving postoperative pain

\footnotetext{
Department of Anaesthetics, Welsh National School of Medicine, Cardiff CF4 4XN

K CHAKRAVARTY, FFARCSI, Commonwealth scholar (present appointment: assistant professor of anaesthesiology, Jipmer, Pondicherry, India)

W TUCKER, FFARACS, research fellow (present appointment: staff anaesthetist, Royal Brisbane Hospital, Queensland, Australia)

M ROSEN, MB, FFARCS, consultant anaesthetist, University Hospital of Wales

M D VICKERS, MB, FFARCS, professor of anaesthetics
}

after upper abdominal surgery, in which we used the final production model of the syringe based on the prototype described. ${ }^{5}$

\section{Subjects and methods}

Apparatus-The demand machine (figure) is a digitally controlled syringe pump' (Cardiff Palliator, from Pye Dynamics Ltd, Bushey, Herts) that delivers preset volumes at a predetermined rate from a disposable Gillette $20 \mathrm{ml}$ syringe. Two digital counters record respectively the total dose and the progress of the current dose. The patient is provided with a press-button hand grip, which must be depressed twice within one second before the machine will respond. This not only prevents the drug from being administered unintentially when the control has been accidentally knocked or dropped but also provides

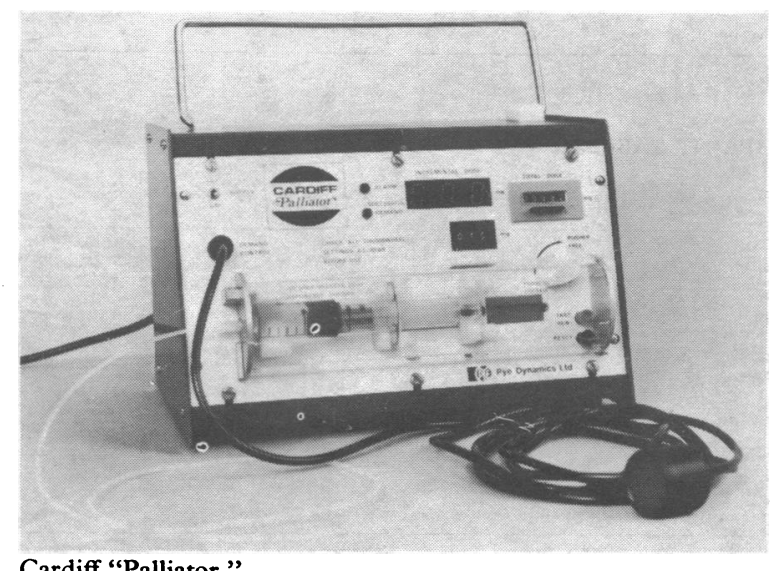

Cardiff "Palliator." 